\title{
[9]
}

\section{Entrepreneurs and the Law: Self-employed Surinamese in Amsterdam}

\author{
Jeremy Boissevain and Hanneke Grotenbreg
}

In the 1970s, immigrants streamed into the Netherlands from Mediterranean countries and former Caribbean colonies, and in particular from Surinam. Many of these immigrants established businesses to supply the specific needs of the newcomers for food, clothing, and entertainment, but because small business in the Netherlands is regulated by a dense network oflaws, they encountered many problems. The same maze of regulations confronts Dutchmen who want to start up on their own, but because immigrant entrepreneurs are unfamiliar with the Dutch language and culture, they have an extra handicap.

We explore the extent to which these laws affect the activities of Surinamese entrepreneurs in Amsterdam. What specific government regulations do they have to deal with in the Netherlands? To what extent are they able to cope legally? How and to what degree do they operate in the informal sector? Do they, in time, change their mode of operation? Do their activities influence government regulations? As far as we can determine, our research is unique in that it examines the effect of law on the activities of immigrant businessmen from three different ethnic groups who arrived from the same country at about the same time-the Chinese, the Creoles, and the Hindustanis from Surinam.

But before reporting on our research in Amsterdam, a brief word about Surinam and the Surinamese, local enterprise, and the experience 
of entrepreneurs in Surinam with government regulations. This background is essential in order to trace the development of Surinamese entrepreneurship and to understand the extent to which their experience with the law in Surinam differed from that in the Netherlands.

\section{Surinam: Chinese, Creoles, and Hindustanis}

Surinam became a Dutch possession after it was captured from the British in 1667. European investors soon established many agricultural enterprises, which brought about an immigration of white officers and plantation managers. Besides capital, the new colonists required labor, but the original inhabitants, the Arawak Indians, proved unsuitable for plantation work, so labor had to be brought in from elsewhere. First came enslaved Africans, an estimated 350,000 of whom were brought to Surinam this way (Lier 1971). The abolition of slavery in 1863 created a new shortage of labor, and plantation workers were recruited on a contract basis from all over the world-first Chinese, then Portuguese from Madeira, and then Lebanese. They soon left the plantations, many becoming traders and shopkeepers. Subsequently an agreement with Great Britain enabled planters to recruit contract labor in India. Increasingly these "Hindustanis" replaced others as the chief plantation work force. In the 1890s, plantation owners also began to recruit Javanese.

The result of this colonial labor policy was that Surinam became a society composed of a rich mixture of race, culture, and religion. Creoles (the descendants of the African slaves), Indians, Hindustanis, Chinese and Javanese, Christians, Hindus, Muslims, and many others now live side by side in one country (Kruijer 1977:9ff.). In this chapter we focus on the Chinese, the Creoles, and the Hindustanis, the ethnic groups from which most of the Surinamese entrepreneurs in Amsterdam have emerged.

\section{Surinamese and Enterprise}

The Chinese conform most closely to the ideal type of middlemanminority described by Bonacich (1973). Many Chinese emigrated to Surinam or were recruited to work as self-employed (Heilbron 1982:232). As a trading minority, they dominated the distributive sector of the 
Surinamese economy. Chinese associations were active in Surinam, not only in the leisure field. They played an important role in organizing rotating credit associations that gave members access to capital. On the national level, these associations acted as pressure groups, representing the interests of more powerful Chinese to government and influencing trading practices, including pricing. There were important patronage and kinship links between the small neighborhood grocers and the wealthy merchants (Vermeulen 1984:92-96). It is interesting that Chinese immigrants in Amsterdam have so far not become heavily involved in retail trade. They left Surinam relatively late, and upon arrival found their traditional economic niche in Amsterdam occupied by the Hindustanis, so they turned instead to the restaurant field, where Indonesian and Hong Kong Chinese were already active. Their activities are now expanding.

The relationship between the Hindustanis and self-employment is somewhat more complex. Hindustanis were originally imported to Surinam as contract laborers for the plantations. On termination of the contract, however, they were offered the choice of remaining and becoming landowning peasants, and many did just that. But the first Hindustanis to become active in trade were not descendants of contract laborers. Many British Indians came to Surinam as traders and there recruited other Hindustanis to assist them (Heilbron 1982:149ff.). The growth of the city of Paramaribo is paralleled by the movement of Hindustanis to the city and its environs. Increasingly they began to produce vegetables and fruit for the city's markets, and organized transportation between rural areas and the city. Tradesmen, transport owners, and small farmers are entrepreneurs par excellence. They are accustomed to independence, making decisions, coordinating the family enterprise, and above all, saving to protect themselves against unforeseen events. The activity of Hindustanis in Amsterdam in the fruit and greengrocery sector is simply an extension of their activities in Surinam.

The experience of Creoles was very different. After failing as peasant farmers following their manumission, Creoles became increasingly involved in wage labor and crafts. Though at first active as market traders, they were gradually replaced by Hindustanis, who had closer links with rural suppliers (Kruijer 1977:69). In Surinam there are far more Hindustani and Chinese shops than Creole shops. Creoles are more active in the civil service, as white-collar workers in the larger firms, and above all, as skilled and unskilled wage laborers with the large companies that were exploiting Surinam's bauxite and timber wealth. Many Creoles are 
unemployed and are obliged to "hustle" in Paramaribo in order to survive (Gelder 1984). The male Creole custom of spending a good deal of time outside the home with friends played an important role in the Creoles' choosing to establish cafés and coffee shops in Amsterdam.

The Chinese and Hindustanis in Surinam attempted to achieve a better life for themselves and their children through being self-employed. By contrast, the Creoles generally followed another strategy. Not the successful entrepreneur, but the senior civil servant, the professional, the highly skilled industrial specialist, provided ideal role-models for Creoles. These were positions that could not be attained without considerable further education, so this helps explain the greater attention Creoles have given to education, something Lier noted forty years ago (1971:186-187). We found that the children of self-employed Creoles generally attained a higher level of education than the children of self-employed Hindustanis (66 percent of Creole children went to advanced secondary schools or to the university, as opposed to 47 percent of Hindustani children-even though many more Creole children came from working-class backgrounds. (The average age of the children may have played a role here too. Creole children were slightly older, around sixteen, whereas Hindustani children were about twelve years old.)

In short, the socioeconomic background of these immigrant entrepreneurs and their experience with Surinamese laws regulating small business influenced their behavior in the Netherlands.

\section{Regulations in Surinam}

The Surinamese regulations governing the establishment of craft enterprises, shops, restaurants, and cafés required registration in the Register of Commerce, a legal idea derived from Dutch laws, but Surinamese authorities took local conditions into account and adapted the rules accordingly. Since 1955, Surinam has had a high degree of independence in internal affairs, and its laws reflected this.

After 1910 all established businesses had to be recorded in the Register of Commerce, and from 1952 it has been mandatory for certain enterprises to be licensed. Shop licenses were granted by the district commissioners, who were also empowered to regulate the types of enterprises requiring licenses. In general, such "permission chits" were granted to hawkers without difficulty.

Aspiring entrepreneurs were checked on several grounds: level of 
education, knowledge of their field and/or experience, creditworthiness, and whether that area was already overcrowded. But the requirements were not stringent. It was not necessary to obtain a diploma to demonstrate administrative capability, and the required level of professional expertise was "minimal," according to the specialists consulted. Furthermore, ordinances regulating conditions of work and personnel did not apply to so-called "family enterprises"; in fact, workers in enterprises employing less than thirty people had very little protection (Gelder 1984:135ff.). Payroll deductions were only introduced in the 1970s, and income tax a few years before that.

Many businessmen did not obtain the required licenses because they refused to pay bribes. One remarked to us:

You have to pay "tjoekoes" for licenses. I did not want to get involved in that, so I worked without a license. I registered my business in someone else's name. Everyone knew that. The reason I did not obtain a license had to do with the fact that a distant relative was a member of Parliament. He was one of the biggest butchers in Paramaribo who supplied institutions. He worked against me. He was afraid that we would outdo him. He was naturally worried that others would obtain supply contracts.

Not having a license had never hampered this businessman's activities, but other people were able to obtain the necessary diplomas on the basis of work experience and could thus legally establish themselves as selfemployed.

To summarize, then, many economic activities that were not in conformity with the law took place in Surinam. The official registration system left much to be desired. Loopholes in the existing laws, and inadequate controls, were responsible for a good deal of the irregularity, and many successful entrepreneurs appeared to be totally ignorant of the relatively simple regulations.

\section{The Surinamese of Amsterdam}

Immigration of Surinamese to the Netherlands has a long history, but until the 1960s the numbers of Surinamese were limited. After that they increased slowly until 1968, and then more rapidly, reaching a peak in 1974 and 1975. After the independence of Surinam in 1975, migration declined sharply, to rise briefly toward the end of the 1970s. 
During the 1950s and 1960s, Surinamese immigrated to the Netherlands to find work, to study, and to assure a better life for their children (Budike 1982:52). During this period, the migrants were relatively wellto-do Creoles, but in the 1970s the social composition and the motives of the migrants shifted. Growing tension between the political and ethnic groups as Surinam approached independence encouraged many lowerclass Surinamese to migrate. Large numbers of Hindustanis, worried about the political future of their own ethnic group following independence, also left for Holland. Of the estimated 180,000 Surinamese in the Netherlands, 40,000 now live in Amsterdam. Of these, approximately 65 percent are Creole, and 28 percent are Hindustani. The balance is composed of those of Chinese and Javanese descent.

The entrepreneurial activity of Surinamese in Amsterdam reflects their migration history. The first tropica shops, which sold a variety of Surinamese fruit, vegetables, and groceries, were established in the 1960s. A Surinamese bookkeeper began to import fresh vegetables from Surinam in 1964, but before that there had been no importation of fresh tropical fruit and vegetables. The tokos, shops catering to Indonesian immigrants, had sold mainly dried vegetables. Indonesian migrants had become used to making do with various substitutes purchased on the Dutch market.

The market for fresh tropical vegetables and fruit expanded with the stream of Surinamese immigrants, and tropica shops multiplied rapidly. Another entrepreneur stimulated this expansion by buying up twentyfive shops, converting them to tropicas, and renting them out, obliging the new tenants to purchase from him the fresh fruit and vegetables they needed. During the 1970s, Surinamese entrepreneurial activity diversified. Travel agencies, small restaurants, barbershops, butchers, cafés, driving schools, record shops, and more recently video shops joined the tropicas. This development has been extremely rapid, especially during the last six years. In 1983 there were approximately 250 Surinamese enterprises in Amsterdam. ${ }^{1}$ The average age of the owners was thirtyeight, and the businesses had been established for about five years. Entrepreneurial activity is concentrated in retailing, catering, and crafts, and most enterprises are located near the open-air markets in the

1Our research was limited to Amsterdam; to craft, retail trade, and catering; and to entrepreneurs who had separate premises. The entrepreneurs studied were self-employed and pursuing an economic activity independently on their own account and at their own risk. Most enterprises have less than ten employees. 
Table 9.1. Surinamese Business Activity by Ethnic Group

\begin{tabular}{lrrcrr}
\hline \multicolumn{1}{c}{ Business } & Creole & Hindustani & Chinese & Other & Total \\
\hline Tropica & 0 & 27 & 6 & 1 & 34 \\
Record/video & 6 & 7 & 1 & - & 14 \\
Barber & 10 & 1 & - & - & 11 \\
Goldsmith & 1 & 2 & - & - & 6 \\
Butcher & - & 4 & - & - & 4 \\
Garage & - & 2 & - & - & 2 \\
Tailor & 2 & 2 & - & - & 47 \\
Coffeeshop & 24 & 3 & 16 & - & 19 \\
Café & 17 & - & - & - & 47 \\
Restaurant / snack bar & 11 & 14 & 5 & - & 35 \\
Travel agency & 6 & 19 & 29 & 7 & 214 \\
Miscellaneous* & 15 & 19 & & & \\
$\quad$ Total & 92 & 86 & & &
\end{tabular}

*Includes diverse shops and market stalls.

older section of the city, where real estate is relatively inexpensive. For this reason, many immigrants settled there too.

Ethnic background plays an important role. Hindustanis and Chinese are, relatively speaking, more active than Creoles. Although Hindustanis form only 28 percent of the Surinamese population in Amsterdam, they control 40 percent of the enterprises. The Chinese are even more active. Hindustanis are most strongly established in retail trade, while Creoles and Chinese are concentrated in catering, as are Javanese (see Table 9.1). The reasons for the uneven spread of entrepreneurial activities are explored elsewhere (Boissevain and Grotenbreg 1986).

So the experience they brought with them from Surinam, their compatriots' demand for specific goods and services, and the existing opportunities in the Netherlands shaped the activities of the immigrant entrepreneurs. The majority established their enterprises in the so-called "formal sector" without further reflection. There they came face-to-face with the rule of Dutch law.

\section{Self-Employment and the Law in the Netherlands}

In the Netherlands, small entrepreneurs are bound by a great variety of rules that regulate establishment of an enterprise. These include municipal licenses, ordinances, and laws governing payment of taxes and social contributions. 


\section{Rules Regulating Establishment}

Rules regulating the establishment of an enterprise date from the economic crisis of the 1930s. In 1935, conditions for establishing an enterprise in Amsterdam were formulated for the first time. Entrepreneurs need to be creditworthy and technically competent, and they had to establish that there was a "need" among consumers for the new enterprise. The object of these regulations was to counter the "fatal" growth of small businesses, which were being set up in response to increasing unemployment (Riel 1961:17). In 1937 the Establishment of Small Business Act came into effect at the national level. Although the new law did not include the "need" element referred to above, entrepreneurs still had to demonstrate that they had the necessary trade expertise and knowledge. This new requirement was an attempt to raise the level of competence in the trade, but it was also a legal barrier to entry. The object of this act and the 1954 Business Establishment Act was to promote orderly entrepreneurial activity.

The 1954 Business Establishment Act, the 1964 Beverage, Hotel, and Catering Act, and the 1971 Retail Trade Establishment Act provided a dense network of rules regulating the establishment of new enterprises. Regulations applicable to entrepreneurs include the following:

1. Enterprises must register with the Chamber of Commerce and the Register of Commerce.

2. All entrepreneurs active in a branch falling under establishment regulations must comply with those regulations. Exemptions from the trade knowledge/expertise provisions can be applied for at the Chamber of Commerce. Exemptions are granted on the basis of similar foreign diplomas, pressing local consumer needs, and "special cases." An entrepreneur more than forty years old who has had many years of experience in the field in which he wants to establish himself may also be granted an exemption after passing a practical examination.

3. Although a license is normally granted only if an entrepreneur has the required diplomas, he can also comply with the law by employing someone possessing a license.

The various laws governing establishment affect the entrance to the market of both local and foreign entrepreneurs. In practice it is extremely difficult for a foreign-born entrepreneur who has the required 
diplomas to obtain a license. The "pressing needs" and "special cases" are rarely judged acute enough to warrant an exemption. One consequence of this web of regulations is that those already in the field are protected against new entrants (Menger 1980:6).

\section{Municipal Licenses}

Entrepreneurs are also required to obtain municipal licenses for a range of activities - for example, for being open on Sundays and public holidays, remaining open after 6 P.M., playing music and running a catering establishment that serves alcohol. Various building licenses are required too, and restaurants must obtain a license to use the sewers. Those who want to use the terrace or sidewalk in front of their premises must obtain a special terrace license. Moreover, under the terms of the Beverage, Hotel, and Catering Act the municipality not only regulates the furnishing and equipment of catering establishments but also controls the morality and age of the owners. ${ }^{2}$

\section{Taxes and Social Security}

Finally, entrepreneurs are responsible for payment of income tax, value-added tax, and social security payments, among other things. They must also withhold from their employees' salaries income tax and the various contributions for which they are responsible under no less than nine different Social Security laws.

A number of special rules apply to children who live and work with entrepreneurs but who do not fall under any employee-insurance regulations. Income tax, old-age pension, and unemployment contributions must be paid on the salaries of children over fifteen years of age. Children who are still required to go to school (usually up to the age of fifteen) may do no work at all. Children no longer obliged to attend school may work up to eight hours a day. Employers face a legal maze that is steadily becoming more complicated. Municipal inspectors told us that laws regulating the various social contributions are now so intricate that no entrepreneur can possibly comply with them without professional assistance.

Self-employed Surinamese who want to establish an enterprise in the

${ }^{2}$ For example, budding catering entrepreneurs are never licensed if they are legally responsible to a guardian and under the age of twenty-five. 
Netherlands on the basis of their experience in Surinam are confronted with yet another problem. While Surinamese regulations controlling self-employment resembled Dutch regulations, they were loosely enforced. The Dutch regulations are more extensive, more formal, and more severely controlled. Consequently, many Surinamese fail to comply with all the requirements of the law. Others have taken a much easier way out and have established businesses that fall outside the various Business Establishment Acts. These include coffee shops, snack bars (which serve no alcohol), record and video shops (which must sell full video tapes), tailoring shops (except for those making men's clothing), wholesalers, and driving schools. At present, the Dutch government is proposing to restrict the establishment of small restaurants and snack bars by placing them under one of the Business Establishment Acts. This will severely limit entrance to a field that has been relatively free of the red tape of the Business Establishment Act and hence very popular among Surinamese entrepreneurs (Ministerie van Economische Zaken 1982).

\section{Informal Entrepreneurs}

Many Dutch hold stereotypical views on immigrant entrepreneurs. They believe that most Surinamese businessmen would rather stay informal than pay taxes. Most Dutch shopkeepers, and some highly placed government officials, are convinced that ethnic entrepreneurs establish their businesses without the necessary diplomas and licenses. Some researchers state that immigrants "prefer" to establish themselves in the so-called "informal economy," the nonformalized sector (Bovenkerk 1982; Ellemers 1984; Pompe 1984; Tap 1983). The informal economy has many dimensions (see Begeer and Tuinen 1984; Breman 1976; Dijk 1980; Gershuny and Pahl 1980; Godschalk 1985; Nicholls and Dyson 1983), but in this chapter we shall focus on certain of its legal and fiscal aspects.

Informal entrepreneurs are entrepreneurs who do not comply with the following regulations:

1. Registration with the Trade Register of the Chamber of Commerce

2. Possession of the necessary permission to establish a business

3. Payment of value-added and income tax and Social Security contributions

4. Registration of employees, payment of minimum wage to em- 
ployees, deduction of income tax and Social Security contributions from wages and payment to government.

Our minimum criterion is registration of the enterprise with the Trade Register. If entrepreneurs had not even complied with this minimum criterion, we considered them completely informal. It will be seen that the four criteria establish a continuum. If entrepreneurs comply with the first two criteria, chances are they comply with the third and fourth as well. We used these criteria to examine the extent to which Surinamese entrepreneurs in Amsterdam were informal or formal. ${ }^{3}$ We found the following:

1. Trade Register. Of the 252 firms we examined, 83 percent had registered with the Trade Register. Thus 17 percent were completely informal.

2. Permission to establish a firm. Almost two-thirds of the Surinamese entrepreneurs were established in businesses requiring an establishment license. Of these, only 40 percent had obtained the required license or exemption.

3. Payment of tax. Nine out of ten entrepreneurs told us they had paid their income and value-added taxes. Those who had not registered their firms with the Chamber of Commerce naturally paid no tax. We do not know whether those who said they paid tax paid sufficient tax.

4. Registration of employees and minimum wage. These regulations were followed less strictly. In just over 70 percent of the enterprises we found relatives working alongside the owner. This was usually in Hindustani-owned businesses. In Creole firms it was more usual to find nonrelatives employed. While 64 percent of nonrelatives were registered with the labor office, this was done for only 16 percent of the working relatives. Generally speaking, the longer an enterprise had been established, the more often nonrelatives were registered. Enterprises that were completely informal registered none of their employees.

Many of those who were called employees or who were working in the enterprises were friends and close relatives who passed time in the shop and lent a helping hand. One of the entrepreneurs told us: "I would

${ }^{3}$ Unfortunately, a comparison with their Dutch colleagues is not yet possible. To date, surveys and studies of Dutch small businesses have been limited to enterprises that comply with all the regulations (see Tillaart et al. 1981). 
rather get help from my family. For example, if my children don't have anything else to do, they work with me. When they are finished they go back to their homework. They do this in the shop. This means that I can keep my wage costs low. It also means that my children always finish their homework, because I see to that." So we often found children, grandparents, and other relatives working in the kitchen or behind the counter. Most were quite unaware of the stringent laws prohibiting children under fifteen from working in any capacity. Small enterprises are family enterprises. Everyone pitches in when the need arises. The Dutch have made this difficult. Inspectors see to it that the laws are obeyed. Some even maintain that the help of the children is "dishonest competition," although the law does not mention this; it is concerned exclusively with the physical and psychological well-being of the children.

Our informants were reluctant to discuss the salaries they paid employees. It was clear that they found the minimum wage and the Social Security contributions excessively high and had difficulty complying with them. In this they differed little from other ethnic and Dutch self-employed (Broeksma, Hennes, and Jansen 1981; Bovenkerk et al. 1983:147). In a period of rising unemployment, which can especially affect migrants who cannot obtain residence permission unless they are employed, many are willing to work for less than the minimum wage.

So while many Surinamese self-employed are formally "established," a substantial number operate informally. There are several cutural and structural reasons that they cannot or do not comply with the rules, many of which are related to practices brought from Surinam. Some assumed that the Dutch regulations were the same as those in Surinam. Others, especially Chinese and older Hindustanis, have a language problem. There is also a shortfall in the information about the intricate self-employment regulations. Religion and the operation of the exemption procedure also form obstacles. We shall return to these later.

\section{Informal Entrepreneurship: A Technique for Survival}

Informal entrepreneurs can be divided in two categories: those who are completely informal and those who are semiformal-that is, those who have registered with the Chamber of Commerce but have not yet complied with all the formal regulations. The level of education the completely informal entrepreneurs have attained is relatively high. 
Many have had a secondary school or technical education. In spite of this, none was attempting to acquire the required business training or technical certificates. A number of the semiformal self-employed were studying for a certificate. Furthermore, all the completely informal operators had been employed before they established their enterprises, mostly by small entrepreneurs. This was in marked contrast to the semiformal entrepreneurs, 50 percent of whom had been self-employed in Surinam before they started up in Amsterdam.

The personal networks of entrepreneurs are an important resource, for they can provide access to capital and cheap, loyal labor. Completely informal operators had fewer relatives in the Netherlands than those who operated semiformally. Consistent with this, the former financed their enterprises exclusively with their own capital, while the latter were able to secure loans from friends, and even from banks.

At the same time, the completely informal operators seemed to be more interested in financial gain and more optimistic than their semiformal colleagues, and they were less cautious. They chose a business activity to fill what they saw as a need in the market. A number had first started at home, often in the evening, alongside their daytime employment. Gradually they had increased their clients, eventually renting specialized premises. It is difficult to predict how many completely informal operators will become formal by registering with the Chamber of Commerce and acquiring the necessary diplomas and certificates. It was quite clear that, before we interviewed them, many had been unaware of the mass of regulations with which they were obliged to comply. We can only speculate about their future.

We can predict with greater certainty that a number of the semiformal self-employed will formalize their status. The various controllers who check up on them will make them aware of the regulations and laws. Lack of familiarity with the law sometimes has disastrous consequences, as illustrated by the grim experience of Ling.

Ling is fifty-eight years old. When he was twenty-two he went to work in his father's shop. After nine years he wanted to begin for himself. His father gave him 5,000 Surinamese guilders. "You know how it goes. You work at home for your father, so you don't earn anything. You only get some food and you work." Finally, when he was forty-seven, Ling emigrated to the Netherlands. On the advice of his children he bought a large Chinese restaurant in the seaside resort of Scheveningen. The family tried to run the restaurant together. They did not succeed. After two years Ling was bankrupt. The chief 
reason was poor accounting and tax debts. He explained, "The restaurant was profitable only during the summer, but I had to pay tax for a whole year on the basis of the profit margin I had during the few summer months." He could not pay his tax debts. To meet some of these, he sold his house in Surinam. He now lives in a small flat with his wife. He can find no work. Everything is gone.

When they began, most immigrant entrepreneurs paid little attention to formal laws. Their primary concern was the market and establishing and maintaining good personal relations with clients and suppliers. The longer they were in business, the more aware they became of the formal regulations, for the controllers left them no peace. A female shopkeeper told us that she had been "frightened half to death" when she had been told to close her business because she had not been complying with the regulations. She speedily studied for and passed the required examinations. The controllers are not the only source of information about the rules and regulations. Several Hindustanis had contacted lawyers to learn about regulations, but the Chinese relied mostly on already established businessmen for their information. Many café owners were successfully piloted through the tangle of red tape by their breweries.

The most important source of information, however, was not government officials or the Chamber of Commerce or established businesses, but networks of personal acquaintances. Two-thirds of our informants learned about the need to register with the Chamber of Commerce from relatives and acquaintances. The length of time an enterprise has been established and the time its owner has spent in the Netherlands are factors that influence the formalization process. Formalization is also related to ethnic descent.

Formal businessmen can be divided in two categories: those who require an establishment license and those who do not. Of the category requiring a license, 43 percent of the Creoles had complied, while only 29 percent respectively of the Hindustanis and Chinese had done so. Of the enterprises not requiring establishment licenses, 61 percent were Creole, 22 percent were Hindustani and 17 percent were Chineseowned. In terms of overall figures, it appears that three out of four Creole businessmen were completely formal, while this was true for only one out of three Hindustani businessmen. Of the semi-formal entrepreneurs, 15 percent were Creole and 75 percent were Hindustani. The Hindustanis thus seem to be more casual about meeting the requirements of the law than the Creoles. 
A partial explanation for the difference in the formalization of Hindustani and Creole enterprises is that, generally speaking, the Creoles have had a much longer and more intense contact with the Netherlands than Hindustanis. All classes among Creoles consider the European type of education and lifestyle, especially obtaining the diplomas ("or else you are a failure"), necessary prerequisites for social mobility. The Creole's entrance to Dutch culture is thus facilitated by a usually greater knowledge of language and custom than Hindustani or Chinese compatriots have. Creoles thus more readily understand, accept, and comply with Dutch rules. Controllers described Creole businessmen as "docile and obedient." Creoles told us they "obeyed the law to be rid of controllers, who were just doing their job."

Hindustani entrepreneurs had a different attitude. Some pretended they had just learned about certain regulations from us. Later they would ask us if they needed a license. They gave us the impression that they would comply if the fines became heavier and more frequent. Moreover, they were able to "arrange" a great deal through their larger network of relations. Brought up in self-employed families and often with considerable personal experience, Hindustanis, more often than the Creoles, were "operators" who played the system. There are indeed a number of techniques and measures that can be used to survive, quite successfully, in spite of the law.

One of the successful semiformal entrepreneurs, Felix, explained some of his survival techniques to us.

Felix produces and sells beautiful leather clothing, trousers, jackets, and accessories. He calls himself "small" because he has no personnel, and "big" because of his turnover. Last year he sold 80,000 belts. "I continually change my products. That is my strength. Eight years ago I went bankrupt for the first and last time. The tax people took everything, even my stock. I had to begin again from scratch." Since then he keeps no stock, "nothing but my skill."

"Of course I registered my firm with the Chamber of Commerce-I think under the "art" section, or something. What I do remember is that for my leather business I needed a certificate of technical competence. Friends told me that. But I didn't have one. For an art business you need nothing. I have a marvelous atelier. But in fact I own nothing. Do you understand? Everything I own is listed in someone else's name. I learned that as a little man in Holland you really can own nothing."

He recently bought a new car, a Suzuki, for 12,000 Surinamese 
guilders cash. "I don't need credit because as a black I wouldn't get it anyway. I don't need government support either, because if things go badly. . . . Look, I don't pay taxes anymore. Because if you require nothing you need pay nothing. I live comfortably, but I want to take care of myself and not trouble the government for subsidies. In exchange they don't have to bother me."

He does his own "bookkeeping." He pulled out his wallet and took out a long slip of paper. On one side he had listed tobacco, coffee, etc., and on the other side was his income from the sale of his products. "In this land of blossoms and barbed wire, you have to look after yourself, otherwise you get hurt."

There are thus a number of survival techniques. To begin with, it is possible to manipulate various certificates-for example, one can formally register the enterprise in a name of a person who does have the required license or diploma. It is also possible to register the enterprise as one that is license-free, as Felix did. Other informants provided further examples:

To open a garage you must have licenses and certificates of competence. On the other hand, you need none to sell new cars. Furthermore, you need no certificates to become a car breaker. Thus, you can open a garage as long as you make sure you have no formal roof over your head. You can also repair bicycles without a license, but you can't sell new parts-although you can get away with it if your books "show" that you use these parts for your repairs. If you want to become a jeweler-which requires certificates-you register as a tinsmith. For that you don't need diplomas. If you repair one pan a year you meet the formal requirement!

Other survival techniques include telling the judge your son is studying hard for his diploma, or one can even rent or borrow a diploma from an acquaintance who ostensibly forms part of the enterprise. These are some of the techniques used to solve the problem of missing certificates and licenses.

To avoid tax assessment, which in the case of a newly established enterprise takes place only after the first five years, a number of entrepreneurs "terminate" their activities after four years. They drop out of the register and start up elsewhere under a new name. This is why small catering establishments change hands so frequently, police-controllers told us, but the technique is apparently not used too often by the Surinamese. The enterprises we examined that suddenly ceased opera- 
tion after the first five years were usually genuine bankruptcies. The most frequent cause of bankruptcy was the extraordinarily heavy tax assessment brought on by ignorance of the tax obligations. Some were able to stave off bankruptcy by working out a program of repayments. We found that most entrepreneurs engaged professional bookkeepers specifically to avoid tax problems. Those who had encountered severe tax problems had been able to avoid bankruptcy by drawing on the help of relatives and friends. Our entrepreneurs considered bankruptcy a scandalous, dishonorable event to be avoided at all costs. A number of informants told us that by keeping a double set of books it is possible to avoid paying 'too much' tax. One observed, "Half your bookkeeping should be white and the rest black. You cannot do everything black, or they'll catch you and you'll lose everything."

In order to avoid heavy personnel costs, many informants used casual labor prepared to work flexible hours for flexible wages. Quite a number disapproved of using illegal labor that worked below minimum-wage levels, and those who operated in this manner are feared. By taking greater risks, they are able to compete more aggressively, because by cutting overhead costs they can sell their goods more cheaply.

Another factor that contributes to informal activities is the 1954 Business Establishment Act, which creates severe problems for many entrepreneurs, and especially craftsmen. Their informal entrepreneurship is largely involuntary. Dutch laws do not take into account the specific nature of their activities, and many goldsmiths and barbers are unable to meet the conditions of the act. On the one hand, they are generally poorly informed as to the precise details of the regulations. On the other hand, many of those who are well informed have had their applications for exemption rejected. A good example is the case of $\mathrm{Fa}$, a goldsmith.

Fa, a Surinamese Chinese, took over a jewelry shop from a compatriot. He also bought the inventory, which included a number of pieces made of gold of less than 14 carats. According to Dutch law, all gold objects must be at least 14 carats. Fa was not aware of this. When his stock was inspected many pieces were impounded. Moreover, he did not have a license to operate. He thought that with his twenty-five years experience as goldsmith in Surinam he had complied with all requirements, but he learned from the inspectors that this was not the case. His petition for exemption on the basis of his experience was denied-his technical knowledge was deemed insufficient, and he was told he also had to be able to work in silver. The fact that in Surinam only goldsmiths were in demand and his customers in Am- 
sterdam were interested only in gold jewelry was regarded as unimportant. $\mathrm{Fa}$, accompanied by an interpreter, failed his technical test for working silver jewelry, but he is still making jewelry. He is sure that because he now conforms to Dutch regulations regarding the gold content of his jewelry he will be exempted from the requirement to have a certificate of competence in silver.

We are considerably less optimistic than $\mathrm{Fa}$ is, given the inflexibility of those who administer the regulations.

Fa's colleague On was also refused an exemption. On and his brother were operating a snack bar. When he wanted to establish himself as a goldsmith, a craft at which he had worked for many years in Surinam, On applied for an exemption from the required certificates. Although he had a Surinamese goldsmith's certificate, his application for exemption from the Dutch diploma regulation was turned down because he was already able to provide for himself with his snack bar so his case provided no "extenuating circumstance." When we told an official the facts in On's case, the official told us that if On had filed an appeal against the ruling he probably would have been successful. But On was unaware of his right to appeal, and equally ignorant of the way to get through the maze of red tape required to file such an appeal.

The extent to which the actual needs and problems of the entrepreneurs provide the raison d'être of the Business Establishment Act is an open question, although extensive lip-service is paid to this principle (Ministerie van Economische Zaken 1981). From our point of view as researchers, and certainly from our informants' point of view, the people interpreting and enforcing the regulations seemed more intent on applying the letter of the law rather than its spirit. They seemed more concerned about protecting the vested interests of established entrepreneurs than in helping the newcomers.

Surinamese barbers and hairdressers have also been adversely affected by the exemption procedures of the Business Establishment Act. Recently the under-secretary for small and medium-sized business stated: "It is absolutely shocking the way barbers working without correct papers are damaging the established hairdressers. We must put an end to this sort of fly-by-night bungling" (Bouwman 1983:9). While all may agree on the negative consequences of unprofessional informal activities, Surinamese hairdressers are more or less obliged to become fly-by-night operators (cf. Bovenkerk 1983), because those who established businesses around 1975 to straighten their compatriots' hair were unable to qualify for exemption. Although many have had years of experience in Surinam, they are still obliged to attend Dutch technical 
schooling, which has only theoretical instruction in hair-straighting (ibid.). Exceptions to this regulation are not permitted. Nevertheless, those who follow this instruction are given no practical training, we were told, because models for practical demonstration are not available. Thus, those who have taken the course and obtained a certificate of competence are expected to be able to straighten hair on the basis of theoretical instruction only. Surinamese hairdressers, and particularly their clients, find this highly questionable, and the latter are not prepared to experiment.

In short, it is difficult for many Surinamese craftsmen, in spite of their experience, to qualify for exemption from the required Dutch certificates of competence. An informant told us that the Central Industrial Board, which grants the exemptions, maintains that "only the preparation of Afro hairstyles presents a few problems. For everything else customers can be helped by Dutch hairdressers." The board also demands that Surinamese goldsmiths be able to work for Dutch clients, just as Dutch jewelers are able to work for Surinamese. All craftsmen must be treated alike, whether Dutch or immigrant. The extent to which Dutch goldsmiths would be able to provide the mattekloppers, taratee, lontai, and other specialized jewelry that Surinamese customers demand is an open question, of course. Surinamese goldsmiths continue to practice their craft in the Netherlands, but they must do so informally. In Surinam the law concerning crafts was applied flexibly; in the Netherlands this flexibility is largely absent.

In spite of the experience of a number of craftsmen to the contrary, many informal entrepreneurs are in time able to adjust to the requirements of Dutch law. As noted, various inspectors and controllers stimulate this, as do urban renewal programs. Small self-employed operators who do not meet all formal requirements risk missing out on various subsidies that would compensate for their past investments. The municipality recently appointed a specialist to advise ethnic entrepreneurs about their rights. Transition from informal to formal entrepreneurship is in fact a dynamic and differentiated process. Many entrepreneurs have found ways to comply with the regulations and have become completely formal.

\section{The Impact of the Surinamese on the Law}

Dutch law has had an impact on Surinamese entrepreneurs, but the entrepreneurial activity of the Surinamese has also ensured that Dutch 
law accommodates a number of Surinamese customs. One way to effect this is to influence Parliament. A second way is to fight arbitrary application of the law. Researchers working with ethnic groups are often used in this process.

\section{Parliament}

During the passage of the 1971 Retail Establishment Act, it was noted that the law could create problems for entrepreneurs from neighboring Common Market states that applied for Dutch establishment licenses. According to the under-secretary at the time, discrimination against foreigners in 1971 was "a fairly academic question, because today no foreign entrepreneur has actually attempted to establish himself in the retail trade" (Menger 1980:35ff.; emphasis added).

The problem has now been resolved for citizens of Common Market countries. Common Market entrepreneurs obtain exemption in Member States on the basis of certification by their own Chamber of Commerce that they have actually been active as entrepreneurs for a number of years. The under-secretary, however, had been poorly informed. At the time, many Indonesian immigrants owned tokos, and many Surinamese established businesses in the 1970s. Formally, however, they were not considered foreigners because as colonial subjects they had Dutch nationality. In Surinam they were governed by laws that had been specially adapted by Dutch legal experts, but in the Netherlands the regulations governing the establishment of businesses differed.

In the meantime, the Council for Small and Medium-Sized Business questioned whether the minimum level of profitability according to Dutch standards should be applied without further adjustment to ethnic minorities. Entrepreneurial activity, the council argued, is sensitive to cultural background and depends on the cultural norms and customs of people (RMK 1983a:150ff.); it made the same point in a parliamentary submission in 1981. The under-secretary replied that in "exceptional cases" and if "important interests were at stake," solutions could be found in the law's provision for exemptions (Ministerie van Economische Zaken 1981). We have seen that these "provisions" are unable to resolve the problems of goldsmiths and hairdressers. It is our impression that as a matter of principle all self-employed craftsmen are subjected to these objective qualitative criteria and that they are strictly administered. Yet when government established these criteria, there were virtually no foreign-trained immigrant craftsmen and businessmen to 
take into account. The criteria were intended for ordinary Dutch entrepreneurs catering to Dutch consumers, so no attention was given to the specific skills and qualifications of hairdressers and goldsmiths required by immigrant consumers. On the other hand, the specific needs of and demand for Muslim butchers did receive attention.

\section{Muslim Butchers}

Muslims are forbidden to eat meat from certain animals, such as pork, and meat that has not been ritually slaughtered. Most Muslims objected that Dutch butchers did not slaughter ritually and that they prepared and sold pork products too. The meat they sold was therefore unclean.

One Surinamese entrepreneur, Ben, established a Muslim association in 1969 when he was forbidden to continue slaughtering ritually. His initiative was followed in many cities. In 1975 the Federation of Muslim Organizations in the Netherlands was founded. The federation became a spokesman for all Muslims in the Netherlands, and it finally scored on the question of ritual slaughtering. In 1977 the government decreed that ritual slaughtering could be carried out in a number of large slaughterhouses. This put an end to the clandestine slaughtering that had been taking place and also met the wishes of the federation. Muslims got permission to open butcher shops if they passed a simple practical examination. Thus, the government was willing to make an exception for problems arising from religious beliefs. The precedent for this had been complaints of Orthodox Jewish poulterers after introduction of the Meat Inspection Law of 1922. They too had been granted an exemption.

The Industrial Board for Trades further refined the exempt status of Muslim butchers. To assure a reasonable turnover and to meet customer needs, one Muslim butcher was authorized for every 1,000 single Muslims and heads of families (about 1,600 Muslim residents). Some officials are unhappy about the way the regulation has been applied- "How do you determine that there are more than 1,600 Muslims resident in an area?" Second, the budding butcher remains completely dependent on the board, which grants the exemptions. Without an official butcher's diploma, a person does not have the right to a license. In the meantime, supplementary vocational training courses for butchers have been organized for people more than twenty-eight years old who do not yet have their certificate of competence.

It is interesting to note that the "need" factor-abolished during the 1930s - has been reintroduced to meet the needs of Muslim customers 
for ritually clean meat. It is ironic that the government has refused to accept the need element when considering the special needs that Surinamese have for their own hairdressers and goldsmiths. Ethnic spokesmen attribute government support of diploma requirements to its wish "to protect existing enterprises" (Leeuwen 1984:32). It appears that established businesses are being protected against newcomers. It is important to note that the only exemption granted on a statutory basis (other than ad hoc exemptions) has to do with religious belief. The structural permutations that stem from diverse beliefs are fundamental political principles in the Netherlands that are also reflected in policy regarding broadcasting and education.

There are also many active Muslim butchers who have not been granted formal exemptions, and this has antagonized Dutch butchers who must comply with strict requirements. Moreover, many question the authenticity of the ritually slaughtered meat, their concern being shared by some of the authorized Muslim butchers. As Ben put it: "I had to wait six months before I could open my business. I had to be able to prove that I had worked in Surinam as a butcher. The others begin just like that. They are even open on Sundays." Another observed: "When they run into problems in a year or two and have to pay tax and get inspectors on the doorsteps, they will simply stop. The shop gets a new owner."

It is possible that in the future legally established Muslim butchers will organize to fight competition from informal rivals by demanding stricter government control. This would not be the first time immigrant entrepreneurs resorted to such measures. In the late 1930s, Italian icecream sellers multiplied so rapidly that they successfully petitioned the government to limit their number (Bovenkerk, Eijken, and BovenkerkTeerink 1983:168). Turks engaged in the rag trade have organized themselves for other reasons. They have attempted collectively to strengthen the position of their enterprises by arranging for a training course that takes their specific problems and cultural background into consideration (Tap 1983). It is clear that national and interethnic Muslim organizations have made an impact on the law.

\section{Salt Beef}

The interpretation of laws often presents a problem. It is not always possible a priori to determine whether something is legal. Recently arrived immigrant entrepreneurs do not protest too much the comments of officials or the fines they levy. This can change as they gain experience 
and are continually obliged to defer to the wishes and interpretations of the officials, "who are well aware that we work this way." One way to determine which interpretation is legal is by means of a court case.

Shopkeepers long ran the risk that if they sold salt beef to their clients they could be fined for cutting it up. Salt beef, a Surinamese staple, is imported in large chunks in vats of brine. The shopkeeper chops these chunks into smaller pieces according to the needs of his customer. This operation is similar to the way a grocer slices ham or sausage. The Meat Inspection Service classified salt beef as processed meat and saw nothing illegal in shopkeepers carving it up but the Economic Control Service disagreed.

Lo, who had been running a grocery shop for eight years, was inspected by the Economic Control Service. The inspector saw him preparing salt beef and regarded this as "the unauthorized exercise of the butcher's profession." The Economic Control Service ruled that because Lo was operating as a butcher he had to have a special permit or an exemption. He had neither. In 1981 Lo was fined to a total of 750 guilders for acting as a butcher. The Economic Police judge charged the magistrate to carry out further research. Lo, who spoke only broken Dutch, hired a lawyer, who pointed out to the magistrate that the Meat Inspection Service had classified the beef as processed meat. The Economic Control Service finally accepted this. It advised the police in writing that the "suspect" in fact did not have to possess a butcher's permit or exemption. Lo was acquitted by the judge, who ordered reimbursement of his fine. He had to pay the 1,200 guilders lawyer's fee out of his own pocket.

If influencing the interpretation and implementation of laws is an indication of social power, then the salt-beef affair can be viewed as a slight shift in favor of ethnic entrepreneurs. In general, the inspection services maintain a reserved policy toward "unknown" or "cultural" products. As long as there is no direct threat to public health, they pay little attention to articles in the so-called "gray zone"-products that are not specifically listed in the law and are sold only to a restricted clientele. We found that older inspectors generally stressed information and were more prepared than their younger colleagues to warn and advise entrepreneurs who were in danger of being fined.

Sometimes threats help to keep inspectors at a distance. The immigrants' lack of information about the manner in which inspectors and quality-controllers operate, and the ignorance of the latter with regard to the culture and customs of the former, cause frequent clashes. More- 
over, there is no uniform local or even national policy. This lack of a uniform policy was seen as a problem by many of the inspectors and it causes considerable confusion among entrepreneurs, especially those who have branches in different municipalities. One informant gave us an example of his frustration: "We even had weekly inspections! It became so bad that the girl behind the counter, who had been with me for years, finally had enough. She grabbed the meat cleaver from the chopping block and waved it at the inspector: 'Just you come back here once more!' He naturally ran off. I had to appear before the regional director, but there I was finally able to unburden myself. Now we are inspected only once a year."

Inspectors told us that businessmen from other ethnic groups occasionally threatened violence. Some Dutch shopkeepers also threatened to close down and fire all their workers if violations were reported-a severe threat in these times of economic recession. Sometimes inspectors take such threats seriously and are lenient, for they realize that heavy fines can indeed bankrupt a small business. Thus, threats occasionally have the desired effect.

A final factor contributing to the (re)interpretation of law is the activity of researchers. When the entrance of immigrants into the market became socially relevant-because of its employment potential and its assumed positive impact on increasingly racist public opinion-the government became interested in ethnic entrepreneurship. Although the Ministry of Economic Affairs ultimately financed our research, we proposed it, and the research drew the government's attention to a number of problems. Some steps have been taken-for example, we noted that while Dutch consumers paid only a 5 percent value-added tax for staples, Surinamese consumers were obliged to pay a 19 percent tax because their staples were classified as "exotic" and "unknown." The Dutch Ministry of Finance is now taking steps to resolve this discrepancy. We also pointed to the inadequate operation of the government's advisory services. Advisory pamphlets for starting entrepreneurs were subsequently prepared in several languages (though not in Chinese), and a special minority adviser was employed. At Lo's request we advised his lawyer about the Meat Inspection Service's classification of salt beef as "processed meat," which was instrumental in winning the case. The minority bill of 1983 also included a paragraph on ethnic entrepreneurs. Finally, the Ministry of Economic Affairs sent banks a copy of our report, in which we noted that Surinamese entrepreneurs believed that they were being discriminated against when they applied for loans. 


\section{Surinamese Commercial Interest Groups}

In principle, Surinamese entrepreneurs should be able to influence the law and its interpretation through political parties and trade organizations. A necessary condition for this is that first-generation entrepreneurs be prepared to cooperate. Most of our informants said they would like to be able to cooperate and were certainly in favor of a pressure group. But they also observed that their relations were determined by the fact that they were not only compatriots but also rivals. They did not cooperate. The very limited cooperation beyond the family level, especially among Hindustanis, was reminiscent of "amoral familism" (Banfield 1958). There was trust among the family members, but suspicion and distrust of nonrelatives. Rivalry is likely to increase, for the number of tropicas and snack bars is multiplying, although the number of ethnic consumers has stabilized, since immigration has virtually ceased.

Shopkeepers also challenge the right of others of sell certain products. One tropica owner remarked: "I cannot follow government policy. When you go to a tropica, you find bakkeljouw, dried fish. The proprietor also sells records and hair cream. He also sells medicine and cooked food. There is also a restaurant. Under which regulation does he fall? Is it a tropica, a restaurant, or a drugstore?" In fact, it is all three. Nevertheless, Surinamese businessmen do not believe it is possible to come together to discuss such problems - or for that matter other problems, such as housing. There is much jealousy and backbiting. A Hindustani businessman (not the only one who expressed a similar opinion) told us: "The Hindustani is asocial. He would rather go to a Dutchman, where he has difficulty being understood, than to a compatriot. He may stumble, but because of status, jealousy, and envy of others, he still goes. Hindustanis are more prepared to accept something from a Dutchman than from one of their own people." One of his colleagues observed that the best mediator would be the municipal government. "We need the strong hand of government to solve these problems." The reluctance of small businessmen and the self-employed to cooperate is certainly not limited to Surinamese. It is a general characteristic of small entrepreneurs (Boissevain 1981:136ff.).

\section{Conclusion}

The widely held view that ethnic entrepreneurs operate informally, cheat, avoid the rules, and pay no taxes is not supported by the facts. 
Although not everyone conforms to all provisions of the Business Establishment Act, this cannot and must not be generalized. In fact, it is surprising that so many do conform to the regulations. In Surinam, after all, lack of a license was hardly a problem. The essential requisites for those who wanted to secure a license were, among other things, the right connections and money. In the Netherlands the Surinamese were confronted with a totally different situation: extensive and complicated regulations, an efficient registration system, and strict supervision and law enforcement. Unquestionably many Dutch self-employed businessmen do not conform to all the regulations of the laws either, but little has been written about them. Therefore, informal entrepreneurship is not static or uniform-it is a dynamic and varied process.

Inspectors play an important role in the process of formalization. They explain to the new entrepreneurs that all entrepreneurs in the Netherlands have a right to a license if they comply with the requirements. The difference between informally and formally established enterprises is only partly a result of the length of time spent in the Netherlands. The longer an enterprise operates, the more often the entrepreneur will have been in contact with inspectors.

A more flexible policy regarding exemptions would solve the problems of such craftsmen as goldsmiths and hairdressers and would entail measures similar to those that were implemented for Muslim butchers. Those measures were the result of pressure groups operating at the national level, which arose because immigrants had to defend themselves against powerful associations of Dutch businessmen that apply constant pressure on the government to enforce regulations in order to keep the outsiders at a distance. The Muslim butchers were regarded as competitors. Exemptions were finally granted some Muslim butchers on religious grounds-a fundamental political principle in the Netherlands. Whether Surinamese entrepreneurs will succeed in establishing an interest group that is able to influence legislation is uncertain. For the time being, each attempts to solve his problems individually. This sometimes involves a direct and not always unsuccessful confrontation with the law.

In the decade or so that they have been active in Amsterdam, 250 Surinamese entrepreneurs have managed to survive in spite of the extensive Dutch laws "regulating" their activities. Most seek to conform to the law insofar as they are able. Many lack the necessary qualifications, though most are willing to acquire these once they are pointed out to them. A few seem to have chosen to remain partly or largely informal. 
Most comply in time. Some with sufficient self-confidence and financial backing have, as individuals, brought about a more favorable interpretation of existing regulations. Lo, the salt-beef champion, brought the Economic Control Service to its knees, thereby benefiting all tropicas, but it is equally obvious that the Surinamese commercial community is weak, because members refuse to or are incapable of organizing themselves to apply pressure to government or to mobilize public opinion. While an individual may force reinterpretation of existing regulations, it appears that laws can be changed only by collective efforts. Ethnic entrepreneurs in the Netherlands are individualists and face a wellorganized structure of small and medium-sized Dutch businessmen, professional associations, semigovernmental industrial boards, municipal and national inspection services and controllers, and a conservative Ministry of Economic Affairs. This solid edifice has a vested interest in maintaining the status quo and will not easily be eroded by the occasional individual chipping away at its foundation.

\section{Acknowledgments}

This chapter is based on Boissevain, Choenni, and Grotenbreg (1984), esp. chap. 6. The research was carried out in 1983 by the authors and August Choenni, assisted by Mariette Meester and financed by the Netherlands Ministry of Economic Affairs. Altogether, we interviewed one hundred people, some at great length. Besides our fellow researchers, we are grateful to R. Fetter, Paul van Gelder, J. Godschalk, A. W. Van der Haas, A. L. Mok, G. Roorda, and Jojada Verrips for their helpful criticism.

Shorter, preliminary versions of this chapter were published in $\mathbf{M i}$ grantenstudies 1 (1986):2-24 (“Ondernemerschap en de wet: Surinaamse zelfstandigen in Amsterdam") and in Revue Européenne des Migrations Internationales 3 (1987):99-222 (Département de Géographie, Université de Poitiers) ("Survival in Spite of the Law: Surinamese Entrepreneurs in Amsterdam”).

\section{REFERENCES}

Banfield, E. C. 1958. The Moral Basis of a Backward Society. Glencoe, Ill.

Begeer, W., and H. K. van Tuinen. 1984. "Statistische operationalisering van het begrip informele economie." In De informele economie: Vereniging voor de Staatshuishoudkunde Preadviezen, pp. 37-39. Leiden. 
Boissevain, J. 1981. Small Entrepreneurs in Changing Europe: Towards a Research Agenda. Maastricht.

Boissevain, J., A. Choenni, and H. Grotenbreg, assisted by M. Meester. 1984. Een kleine baas is altijd beter dan een grote knecht: Surinaamse Kleine Zelfstandige Ondernemers in Amsterdam. Amsterdam.

Boissevain, J., and H. Grotenbreg. 1986. "Culture, Structure, and Ethnic Enterprise: The Surinamese of Amsterdam.” Ethnic and Racial Studies 9(1):1-23.

Bonacich, E. 1973. “A Theory of Middleman Minorities.” American Sociological Review 38:583-594.

Bouwman, M. 1983. “Alles liever dan eeuwig werkloos.” Intermediair 19(48):3-11. Bovenkerk, F. 1982. “Op eigen kracht omhoog: Etnisch ondernemerschap en de oogkleppen van het minderhedencircuit." Intermediair 18(8):1-11.

- 1983. "Zelfstandig ondernemerschap van minderheden." Lecture delivered at the Ministry of Economic Affairs Conference, Rotterdam, September 7.

Bovenkerk, F., A. Eijken, and W. Bovenkerk-Teerink. 1983. Italiaans ijs: De opmerkelijke historie van Italiaanse ijsbereiders in Nederland. Meppel.

Brana-Shute, G. 1979. On the Corner: Male Social Life in a Paramaribo Creole Neighborhood. Assen.

Breman, J. 1976. Een dualistisch arbeidsbestel? Een kritische beschouwing van het begrip "de informele sector." Rotterdam.

Broeksma, C. A., H. Hennes, and A. C. M. Jansen. 1981. “De kleine ondernemer buiten beeld." ESB 66:284-288.

Budike, F. 1982. Surinamers naar Nederland: De migratie van 1687 tot 1982. Amsterdam.

Buenk, B. W. 1980. De Kamer van Koophandel in de Praktijk. Deventer.

Dijk, M. P. van. 1980. De Informele sector van Ouagdougou en Dakar: Ontwikkelingsmogelijkheden van kleine bedrijven in twee Westafrikaanse hoofdsteden. Ph.D. thesis, Free University, Amsterdam.

Ellemers, J. E. 1984. "Etnische verhoudingen in Nederland-de behoefte aan een differentiele zienswijze." Maatstaf 32(9):47-57.

Gelder, P. van. 1984. Werken onder de boom: Dynamiek en informele sektor: de situatie in Groot-Paramaribo, Suriname. Ph. D. thesis, University of Amsterdam.

Gershuny, J. 1978. After Industrial Society: The Emerging Self-Service Economy. London.

Gershuny, J., and R. E. Pahl. 1980. "Britain in the Decade of the Three Economies." New Society, January 3, pp. 7-9.

Godschalk, J. J. 1985. De informele economie: Report for the Council for Small and Medium Sized Business. Amsterdam.

Heilbron, W. 1982. Kleine boeren in de schaduw ven de plantage: De politieke ekonomie van de na-slavenijperiode in Suriname. Ph.D. thesis, University of Amsterdam.

Kroniek van het ambacht/klein-en middenbedrijf. 1983. Special issue: Conferentie Vestigingswetbedrijven, vol. 37.

Kruijer, G. J. 1977. Suriname: De problemen en hun oplossingen. Utrecht and Antwerp. 
Leeuwen, M. van. 1984. “Minderhedenbeleid, discussie en knelpunten.” Kroniek van het ambacht/klein- en middenbedrijf 38:30-34.

Lier, R. van. 1971. Frontier Society: A Social Analysis of History of Surinam. The Hague. First published 1949.

Menger, P.J.P.T. 1980. Vestigingswet Detailhendel. Zwolle.

- 1983. Vestigingswet bedrijven 1954: Vestigingsbesluiten Bedrijfsvergunningenbesluiten. Zwolle.

Ministerie van Binnenlandse Zaken. 1983. Minderhedennota. Parliamentary Document 102(20-21).

Ministerie van Economische Zaken. 1981. Kamerstuk 17, 100 hfdst. 7 (nr.38). "Vragen gesteld door leden van de Kamer, met de daarop door de Regering gegeven antwoorden."

- 1982. Kamerstuk 17, 553 (nr.13). "Het midden- en kleinbedrijf in hoofdlijnen: Beleid inzake het starten van een eigen bedrijf."

- 1983. Toespraak van de Staatssecretaris van Economische Zaken. P. H. van Zeil, Rotterdam, September 7.

1984a. "Voorlichting, financiering en inkomenshulp t.b.v. adspirant-ondernemers: Brief aan de Voorzitter van de Tweede Kamer der Staten-Generaal" (784/2/211/HAD10), May 30.

1984b. De kleine onderneming en de Nederlandse overheid: Informatie over wetten, regelingen en adviesmogelijkheden. The Hague.

Ministerie van Sociale Zaken en Werkgelegenheid. 1983. Het Arbeidsbesluit Jeugdigen. The Hague.

Nicholls, W. M., and W. A. Dyson. 1983. The Wealth of Families: How Canadians Are Responding to Economic Crisis by Tapping Our Base Economy. Montreal.

Pompe, J. H. 1984. "Over Italiaans ijs en Turks textiel." Kroniek van het ambacht/klein- en middenbedrijf 38(1-2):7-21.

Reubsaet, T.J.M. 1981. Surinamers in Nederland, een momentopname. Nijmegen. 1982. Surinaamse Migranten in Nederland: De positie van Surinamers in de Nederlandse samenleving, vol. 2. Nijmegen.

Riel, J. W. G. van. 1961. De Vestigingswet in de praktijk. Utrecht and Antwerp.

RMK (Raad voor het Midden- en Kleinbedrijf). 1983a. MKB-Voorlichtingsinstrumentarium. The Hague.

. 1983b. Bedrijfsgeorienteerde Stadsvernieuwing. The Hague.

Sampson, S. L. 1983. "Rich Families and Poor Collectives: An Anthropological Approach to Romania's Second Economy," pp. 1-25. Paper presented at the Institute for Ethnology and Anthropology, Copenhagen.

Tap, L. J. 1983. “Het Turkse Bedrijf sleven in Amsterdam." Rapport naar aanleiding van een afstudeeronderzoek. Groningen.

Tillaart, H. J. M. van den, H. C. van der Hoeven, F. W. van Uxem, and J. M. van Westerlaak. 1981. Zelfstandig Ondernemen: Onderzoek naar de problemen en mogelijkheden van het zelfstandig ondernemerschap in het midden-en kleinbedrijf. Nijmegen.

Vermeulen, H. 1984. Etnische groepen en grenzen: Surinamers, Chinezen en Turken. Weesp. 